\title{
Economic Aspects of Diversification of Farm Sector: A study of India
}

\author{
Dr. Nisha Singh \\ Livingstone College \\ 701 West Monroe St. Salisbury 28144
}

\begin{abstract}
The primary objective of this paper is to analyze the economic aspects of the landless, marginal and small farmers to surmise solutions on how they can able to supplement their income. To investigate this topic we refer to the world's population and how it was doubled during the beginning of the twentieth century. For instant, in 1950 the population was 2.5 billion and now, in the year of 2016, it stands at 7.4 billion. By 2050 world population is projected to grow up to, approximately, 9 or 10 billion. Most of the growth is expected to occur in rural areas in developing countries, where the income elasticity demand for food remains high (Agricultural statics at a glance, Govt. of India, 2003). One of the top most populated and developing country is India where over two third of the population consist of farmers and their families. The food insecurity and malnutrition among children, women and men are due to the lack of purchasing power. "
\end{abstract}

Key Words: Diversification, Economic aspects, Marginal size, Elasticity, Purchasing power

\section{OBJECTIVE}

Farmers' families in India constitute over two third of the population. The rural population in India, itself, is a class quite different from the urban population. The challenges in the case of small land holding or landless agricultural labor are enhancing the economic value of their time and labor bringing about a paradigm shift from unskilled to skilled workers. Nearly a third of the rural population and a large proportion of women earn their livelihood through wage employment. A massive effort in the area of knowledge and skill empowerment of the women and men constituting the landless labor work force is essential if economic value is to be added to the time and labor. After the mid 1990's Indian agriculture has moved fast towards a diversified high value crops such as fruits and vegetables, livestock and fisheries etc. The increased production of high value crops also resulted in increased agricultural exports, thereby increasing revenue and employment opportunities (The Hindustan Survey of Indian Agriculture, pp-17, 2005). Their skills will have mobilized to enhance the competitiveness of agriculture value-addition to primary products and diversification of livelihood-opportunities. In Uttarakhand and Uttar Pradesh states about 70\% of land holdings are less than 100 acres in size and cover about $27 \%$ of the total cultivated area of $51 \%$. Also, just over $3 \%$ of land holding are above 4 hectares in size and marginal holdings (Table-1), scale of economics cannot be availed of and so the input cost per unit of output is higher. Therefore, it becomes all the more difficult task to make agriculture a profitable occupation. 
Table 1: Size of land holding

\begin{tabular}{|l|l|l|l|l|l|}
\hline S.N. & $\begin{array}{l}\text { Size in sq-hectare (1 } \\
\text { hectare=100 acre, Sq. } \\
\text { feet) } 43560\end{array}$ & $\begin{array}{l}\text { Total land hold in } \\
\text { agriculture }\end{array}$ & Percentage & Total area & Percentage \\
\hline 1 & 1.0 and less & 672723 & 71.7 & 233767 & 26.6 \\
\hline 2 & $1.0-2.0$ & 152701 & 16.3 & 213899 & 24.3 \\
\hline 3 & $2.0-4.0$ & 81402 & 8.7 & 229992 & 26.1 \\
\hline 4 & $4.0-10.0$ & 28813 & 3.1 & 158624 & 18.0 \\
\hline 5 & 10.0 Above & 1840 & 0.2 & 158624 & 5.0 \\
\hline 6 & Total & 937479 & 100.0 & 880132 & 100.0 \\
\hline
\end{tabular}

Sources- Government of Uttar-Pradesh

Since the beginning of our research activities we have put maximum stress on the research, extension and production of major food grains like wheat and rice. However, it was the necessity of those days because India was short of food grains to feed its people. The extensive research work produced high yield varieties thereby increasing the total production. To encourage farmers the government introduced Minimum Support Price (MSP) on major food grains. However, this has resulted in a huge buffer stock. The storage, requiring huge manpower and space, has made our food grains costlier than those in the international market. To make Indian economy to shine, and to increase the farmers' income it is necessary to divert the farming from wheat and rice to the products like vegetables, flowers, dairy farming, fishery, poultry farming, Seri culturing and apiculturing.

\section{International Scenario}

The world scenario in recent times has been changing to liberalization through economic reforms and also due to globalization on account of the creation of WTO. Market economy is now going to play a large role in various economic activities including agriculture. WTO has come up with a number of agreements envisaging commitment on the part of the government to limit access for foreign agriculture products. In this scenario the evergreen or sustainable advanced job opportunities, can be attained only by a quantum jump in productivity per unit of land, water, energy and even per capita income. Reorientation of cropping system mode of farming system to multi-enterprise agriculture (crops, trees, and livestock including fisheries) focused on international synergies by multiple uses of inputs and recycling is expected to expand the livelihood and year round employment.

\section{A Profile of the Study Area}

A survey of the existing literature on economic aspects of diversification of farm sector in some part of Uttaranchal (India) like Haridwar, Dehradun and Udham Singh Nagar have been studied. The districts of Uttar Pradesh (India) like Ghazipur and Varanasi have also been taken in to account. Studies indicate that very little information is currently available on this important issue. The scope for studies in different sub zones within the region with a view to understand the economic aspects of diversification of farm sector has been considered.

Diversification of agricultural crops into high-value of horticulture crops hold considerable promise for the hill region. The impact of such diversification on natural resources is equally important because this region is ecologically fragile. It is recognized that the hill areas have a comparative advantage in horticulture and agro-processing which is favorable in increasing income levels besides being environment friendly. The establishment of small industries based on horticultural crops, forest wealth, tea gardening, herbal and medicinal plants, dairy, fishery in this region will open opportunities of employment for people and increase the income levels. 


\section{METHODS}

This paper is based on true empirical work and the methodology used in this research is primary data. Data has been collected through pre-tested questionnaires from Uttrakhand, Uttar Pradesh, India. These questionnaires have been given in Appendix A. On the basis of data collected in above areas, data analyses including descriptive statistics were performed.

\section{The Role of Integrated Farming Dairy Industries}

India with 87 million breedable bovine population has now reached the top position, whereas U.S.A. with a meager 10.2 million breedable bovine population is second in the world milk production (Indian Journal of Extension Education Vol. 39 No. 1\&2, 2003). Animal husbandry and dairying is estimated to account for $26 \%$ of the total value of agricultural output. About 70,000 dairy cooperative societies involving about nine million farmers have been organized (The Hindustan Survey of Indian Agricultural, pp.39, 1996). Dairy industry of India has witnessed considerable transformation since the inception of Operation Flood programed launched in 1970 by National Dairy Development Board. It is important to note that as a result of concerted efforts towards total dairy development, India today ranks as the largest milk producer and the value of output through dairying in India is the largest as compared to any other agricultural commodity (Pranob Mukherjee, 1995). Over the last two decades, our milk production has nearly tripled and it has now become our largest single agricultural commodity with dairy industry's turnover estimated at more than Rs. 52,000 crores (Banerjee, 1995). India owns one of the largest livestock population in the world. Animal science through various programs of livestock production dairy, wool, hide and others has the potential to grow at a growth rate of 7 to $8 \%$. A very significant aspect of dairy is its potential to provide rural employment (Evenson, et al 1999). Animal husbandry and dairying is estimated to account for $26 \%$ of the total value of Agricultural output. Compared to crop, animal husbandry registered a higher average long term growth of employment as per the estimates of "The National Sample Survey Organization". Landless, marginal and small farmers were able to supplement their income in the sector. In integrated sustainable agriculture, it is necessary to generate income through dairy, fishery, poultry and sericulture etc.

Table 2: Agriculture Economic Value

\begin{tabular}{|l|l|l|}
\hline Name & $\begin{array}{l}\text { Area in acre (reduced to 1 acre, 1 } \\
\text { acre=43545.72 Sq feet ) }\end{array}$ & $\begin{array}{l}\text { Economic Values in Rs. of } \\
\text { one crop (after cost } \\
\text { deduction) }\end{array}$ \\
\hline Satish Kumar Sharma & 1 acre & 35400.00 \\
\hline Gajendra Singh & 1 acre & 34150.00 \\
\hline Jugapal Singh & 1 acre & 35400.00 \\
\hline Rajbahadur Saini & 1 acre & 27700.00 \\
\hline Arvind Kumar & 1 acre & 35150.00 \\
\hline Rajnish Chauhan & 1 acre & 35400.00 \\
\hline Average & 1 acre & 33866.67 \\
\hline
\end{tabular}

Based on table 2 a farmer annually average income is Rs. 33866.67 with standard deviation of Rs. 3059.68 per year if farmer is not using good technology, growing high value vegetation, integrated faming etc.

\section{Milk Procurement and Sales:}

The milk procurement in Uttaranchal stood at 96,930 liters/day (25,606.197 gallons/day) during May 2004. Maximum procurement was registered in Udham Singh Nagar at 45,139 liters/day (11,924.46 gallons/day), (monthly review of Uttarakhand Economy, June 2004, pp 28). For the purpose of the study of economic aspects of dairying the data has been collected 
from some part of eastern U.P. and Uttarakhand. Data has been collected from six (6) subjects from Uttar Pradesh and Uttarakhand states.

\section{Data Analysis}

\begin{tabular}{|l|l|}
\multicolumn{2}{|c|}{ Table 3: Revenue Computation } \\
\hline Area under consideration & 1 acre $(43545.72$ sq. feet $)$ \\
\hline Space required for one cattle & 120 sq. feet \\
\hline Number of cattle per acre & 362 \\
\hline Expenditure per cattle per day & Rs. 100.00 \\
\hline Total expenditure for 362 cattle per day & Rs. $36,200.00$ \\
\hline Average milk production per cattle & 6 litres \\
\hline Cost of one liter of milk & Rs. 20.00 \\
\hline Cost of one liter of milk per cattle & Rs. 120.00 \\
\hline Cost of one litter of milk of 362 cattle per acre & Rs. $43,440.00$ \\
\hline Net profit per cattle per day & Rs. 20.00 \\
\hline Total profit for 362 cattle per day & Rs. $7,240.00$ \\
\hline Total profit for 362 cattle per month & Rs. $217,200.00$ \\
\hline
\end{tabular}

Table 3 shows the revenue generated from 362 cattle per acre of land. Miscellaneous expenditure includes the loan taken on the cattle. On average a farmer has to pay Rs. 500.00 per month as instalment towards the loan he has taken on the cattle. The total average loan he has taken for buying 362 cattle is Rs. 181000.00 . Average cost per cattle is Rs. 20,000, so loan will take about three years' time to recover so after the payment of loan the savings will remain Rs. 36200.00/month. After the loan has been re-paid the profit will become Rs. 217200 .

Cattle gives calf which will be matured in three years. The dung can be used in the place of inorganic fertilizer. Currently 10000 MT of bio-fertilizers are being used in the country. Above 1000 million tons of animal dung is produced in. India annually yields about 500 million tons farm manure which is excellent resources of plant nutrient. An application of 10 tons well rotten $\mathrm{FYM} /$ ha can add 50-60 $\mathrm{kg} \mathrm{K} \mathrm{K}_{2} \mathrm{O}, 300$ million tons crop residues, 285 million tons rural compost, 14 million tons city refuse, 28 million tons Biogas slurry available in the country may be utilized widely as plant nutrient. All these sources contain, on average, $0.5-2.0 \%$ Nitrogen $(\mathrm{N}), 0.2 \%-1.0 \% \mathrm{P}_{2} \mathrm{O}_{5},---0.5-1.5 \% \mathrm{~K}_{2} \mathrm{O}$ (Yojana November, pp 29, 2003)

\section{CONCLUSION}

Dairying is an economic activity with cash flows to the households, in contrast to the income due to crops, which comes only at the end of season. Income from dairying contributes nearly a third of the rural household gross income from (The Hindu Survey of India Agriculture, 2004). Animal husbandry and dairying is estimated to account for $26 \%$ of the total value of agricultural output. As compared to crop, husbandry registered a higher average long term growth of employment as per the estimates of the National Sample Survey Organization. Landless, marginal and small farmers were able to supplement their income in this sector.

\section{Fisheries}

Fisheries sector play a significant role in the food and nutritional security, employment generation and export trade and thus contributes remarkably to the Gross Domestic Product (GDP). The average productivity of tanks and ponds has been estimated at 400-700 tons/acre/year. Fisheries sector play a significant role in the food and nutritional security, employment generation and export trade and thus contributes $1.5 \%$ of total GDP "between" 2004-07. India is the fourth largest producer of the fish globally in the total fish production and stands in inland fish production after China. The share of inland fisheries sector is at $50.8 \%$ of the total fish production in 2002-03. Fresh water aquaculture technology provides for a wide array of culture systems with production levels of 300-400 tons/acre/year in integrated 
farming systems to 1000-1500 tons/acre/year in pond culture to 10000-13000 tons/acre/year flow through and cage culture systems (The Hindu Survey of Indian Agriculture, 1997). A fish productivity level of $155 \mathrm{~kg}$ per fishing day valued at Rs. 1,794 per day. Data has been collected from six (6) subjects from Uttar Pradesh and Uttarakhand states.

Table 4: Data on fish farming

\begin{tabular}{|l|l|l|l|}
\hline Subject & Area in acre (reduced to 1 acre) & $\begin{array}{l}\text { Productivity in } \\
\text { Kg/day (acre) }\end{array}$ & $\begin{array}{l}\text { Economic } \\
\text { Values } \\
\text { Rs/day }\end{array}$ \\
\hline 1 & 1 acre & $160 \mathrm{Kg}$ & 3200.00 \\
\hline 2 & 1 acre & $130 \mathrm{Kg}$ & 2600.00 \\
\hline 3 & 1 acre & $120 \mathrm{Kg}$ & 2400.00 \\
\hline 4 & 1 acre & $155 \mathrm{Kg}$ & 3100.00 \\
\hline 5 & 1 acre & $140 \mathrm{Kg}$ & 2800.00 \\
\hline 6 & 1 acre & $155 \mathrm{Kg}$ & 3100.00 \\
\hline Average & 143.33 & 2866.67 \\
\hline Standard deviation & 6.54 & 130.81 \\
\hline
\end{tabular}

\section{CONCLUSION}

Farm fish production of 400-700 tons/acre/year can be obtained without the use of any supplementary feed and fertilizer. Table 4 shows that the average fish productivity is 143.33 $\mathrm{kg} /$ day with standard deviation of $6.54 \mathrm{~kg} /$ day from 1 acre land. The average cost of 1 acre fish productivity is Rs. $=2866.67$ and the standard deviation is 130.81 . Total harvesting time is approximately 10 months. Therefore, total harvesting period will become 300 days. One day harvesting value is equal to Rs. 860001.00. Total Expenditure is equal to Rs 80000.00 for 10 months which included weed control, Eradication of unwanted fish, Lime application, fertilization application, stocking. Therefore the net profit from fishery is Rs. 780000.00 per year

\section{Mushroom}

Mushroom have always attracted man's attention mainly due to their varied color, shape and appearance. In India the white button mushroom (Agaricus biisporus) is the main commercial mushroom followed by dhingri (Pleuroutus Sajor Caju) and paddy straw mushroom (Volvariella volvacca) cultivated in selected pockets. Mushroom contains 23-30\% proteins. Mushrooms have been identified as efficient means for conversion of worthless agro wastes into valuable protein. Common substrates used for mushroom production are wheat straw, paddy straw, sugarcane bags and chicken manure but other wastes such as cotton stalks and waste, cordust, stalks and leaves of pulses and oil seeds can also be used. Abundance of a variety of agro-wastes at low prices in various parts of the country is another big strength. Mushrooms are cultivated indoors and do not require arable land. Small farmers and less workers constitute a major fraction of the population and mushroom cultivation suit their economic and social security. Mushrooms grow in a controlled environment through the year. It will be interesting to know that six developed countries alone consume more than $85 \%$ of the global production and represent the most important mushroom markets (The Hindu Survey of India Agriculture-1996).

\section{Poultry}

India's share in the world egg trade is estimated at 1500 tons ( $\mathrm{I}$ ton $=907.185 \mathrm{Kg}=1360777.5$ Kg) worth Rs. 81.74 millions. Contribution of Animal husbandry to national GDP is 9\% (The Hindu Survey of Indian Agriculture pp.6-7, 2004). Export projection for poultry and its products in year 1999-2000 was 4682 million rupees in which poultry egg of poultry was 425 million Rs. poultry meat was 1991 million Rs. and live poultry was Rs. 16 million. Data has been collected from six (6) subjects from Uttar Pradesh and Uttarakhand states 


\section{DATA ANALYSIS}

Data has been collected through pre-tested questionnaires. It has been collected from some part of Uttaranchal and from Eastern U.P (Varanasi and Gajipur). Average profit from poultry farming is Rs. 870880.00. One Broyler seeds cost is Rs. 11.00 and apace for one chick is 2 square feet and one acre land is equally 43545.72 sq. feet. So total hen in one acre is 21772. Feed for one hen in 28 days $2.50 \mathrm{~kg}, 1 \mathrm{~kg}$ feed cost is Rs. 11.00 so total cost of $2.1 / 2 \mathrm{~kg}$ feed is 27.50, vaccine cost is Rs. 2.00 and other expenditure is Rs. 10.00. Total expenditure on 1 hen is Rs. 60.00. Cost of $1 \mathrm{~kg}$ chicken is Rs. 90.00 and net profit from one chick is Rs. 30.00 within one month. In 21772 hens have 10000 she hens which lays eggs in which approximately 500 die from some time environment, eases etc. 11272 hen used for meat which cost is Rs. 338160.00.

\section{Fish-Poultry Farming}

Poultry wastes in aquaculture are normally used as a supplement to conventional feed. 25$30 \%$ of poultry by product can be used in the supplementary feed for fish. It is observed that for an integrated system of fish-poultry farming, about 500-600 birds are required to fertilize 1 ha. Pond to produce 4-5 tons fish/ha/yr. It is estimated that $17.20 \mathrm{~kg}$ of manure are produced daily per $1000 \mathrm{~kg}$ broiler live weight. Composting of chicken manure showed $3 \% \mathrm{~N}, 2 \% \mathrm{P}$ and $2 \% \mathrm{~K}$ in the composition and one adult chicken produces $25 \mathrm{~kg}$ of compost manure in one year (Yojana November 2001).

\section{Apiculture}

In integrated sustainable agriculture, it is necessary in generate income through various activities of which beekeeping is one. Apiculture is actually a low investment activity and does not compete for inputs with other segments. It increases productivity by aiding in the process of pollination. Table 5 shows the production of honey is increasing continuously in year 1953$54,1200.00 \mathrm{~kg}$, in $63-64$ it is $712705.01 \mathrm{~kg}$, in $73-74$ it is 30620.1 , in $84-85$ it is 54394440 , in 90-91 it was 9283750.00 and in 93-94 was 5525700. Average production of one beekeeper is 3 $\mathrm{kg}$ honey. $1 \mathrm{~kg}$ honey costs Rs. 120.00. Therefore, the market cost of $37 \mathrm{~kg}$ honey is Rs. 4528.65 per month. In this way land less people can earn respectable income.

Table 5: The Hindu Survey of Indian Agricultural

\begin{tabular}{|l|l|l|l|l|}
\hline Year & No. of beekeepers & No. of colonies & Honey total (tons) & $\begin{array}{l}\text { Production average } \\
\text { (Kg/colony) }\end{array}$ \\
\hline $1953-54$ & 234 & 800 & 1.28 & 1.50 \\
\hline $1963-64$ & 57198 & 164597 & 7.13 & 4.33 \\
\hline $1973-74$ & 150421 & 522714 & 2435 & 4.65 \\
\hline $1984-85$ & 200000 & 868000 & 5500 & 6.33 \\
\hline $1990-91$ & 246000 & 1061000 & 9288 & 8.75 \\
\hline $1993-94$ & 236000 & 678000 & 5529 & 8.15 \\
\hline $2005-06$ & 250,000 & 17503820 & 11425.47 & 15.32 \\
\hline
\end{tabular}

Sources: The Hindu Survey of Indian Agricultural 2006, KVIC-2005-06

\section{EXPECTED RESULTS/ CONCLUSION/ CONTRIBUTION}

Environmental and financial motives were found to be the primary motives behind the farmers' diversification of farm sector; dairying, fisheries, silk industries, mushroom culturing, poultry, fish-poultry farming, and apiculture. Diversification of agricultural crops into highvalue of horticulture crops, secondary and tertiary sectors of the economy. Animal husbandry and dairying is estimated to account for $26 \%$ of the total value of Agricultural output. Compared to crop, animal husbandry registered a higher average long term growth of employment as per the estimates of "The National Sample Survey Organization". Landless, marginal and small farmers were able to supplement their income in this sector. In integrated 
sustainable agriculture it is necessary to generate income through dairy, fishery, poultry and sericulture etc.

Table 6: Summary of annual economic value by integrated farming

\begin{tabular}{|l|l|l|l|}
\hline S.N. & Size of Land & Integrating Farming & Annually Economic Value in Rs. \\
\hline 1. & 1 acre & Agriculture & $71066.00 \quad(35533.00$ per crop x2) \\
\hline 2. & 1 acre & Dairy & 217200.00 \\
\hline 3. & 1 acre & Poultry & 338160.00 \\
\hline 4. & 1 acre & Fishery & 780000.00 \\
\hline 5. & 1 acre & Apiculture & 30000.00 \\
\hline
\end{tabular}

India's food management system has undergone tremendous changes since the green revolution during late 1960 s. On the other hand about $26 \%$ population is reported to be below poverty line and is undernourished. The rising domestic price of rice and wheat has made these commodities costlier at international level. On the other hand the production of all seeds, pluses, meet items etc. is for less than over demand. Therefore, farmers need to divert their attention to the production of non-cereal crops as cash ready commodity.

Education has been found to be the strongest contributing factor for a farmer to adopt integrating farming. Therefore, more number of educated conventional farmers may be made aware of the benefits of diversification. The integrated farming systems where milk, fish, poultry, silk, honey and mushrooms are produced in combination so that the byproduct of one is used as feed are fertilizer for the other. This kind of farming will help the farmers to increase their income. Further, environmental and financial motives were found to be the primary motives behind the farmers' conversion to integrated farming. In addition to the net profit advantage of integrated, other hidden environmental benefits of it should also be brought to the notice of conventional farmers. Fish production can be obtained 4-7 tons/ha/yr without the use of any supplementary feed and fertilizer. The average fish productivity is 143.33 $\mathrm{kg} /$ day from 1 acre. The average cost of 1 acre fish productivity is Rs. 2866. Total harvesting time is approx. 10 months. Therefore total harvesting period will become 300 days in year. One day harvesting value is equal to Rs. 2866.67 so 10 month 780000.00.Dairying is an economic activity, in which cash flows to the households, in contrast to the income due to crops, which comes only at the end of season. Income from dairying contributes nearly a third of the rural household gross income (The Hindu Survey of Indian Agriculture, 2004). Compared to crop husbandry, animal husbandry registered a higher long term growth of employment as per the estimates of the National Sample Survey Organization.

\section{References}

Agricultural stastics at a glance, Govt. of India (2003).

Alston, Julian M. et al., 2000, “A Meta-Analysis of Rates of Return to Agricultural R and D: Ex Pede Herculem”. Washington, D.C.:International Food Policy Research Institute.

Adoption of Organic Farming Profit and motives of Farmers Indian Journal of Extension Education vol. 39, No. 1\&2, pp.35, 2003.

Banerjee, A, Togetherness in Dairying, Indian Dairyman, 1995, Vol. 47 No. S.2-3, pp. 10.

Crosson, Pierre, 1995, “Soil Erosion and Costs, science 269:5223”, pp 461-63.

Department of Agriculture, Uttarakhand, Tenth Five-Year Plan 2002-07, and Annual Plan 2002-03.

Etienne, G. 1993, "Indian Village and Districts Revisited, The Issue of Economic Growth and Poverty", Indian Journal of Labor Economics, Vol. 36, No-2, April-June.

Economic Survey, Government of India, Ministry of Finance, Economic Division pp 150-155, 2001.

The Hindu Survey of India Agriculture, 1996, pp. 123.

Hindustan Times, New Delhi, April 13, 2003 
Hayami and Ruttan , 1970, “Agricultural Productivity: Difference Among Countries”, American Economic Review. December, 60:S. pp. 895-911.

Indian Journal of Extension Education, A Major Success Story, S. Shanugarundaram

Irrigation Management ICAR, RCER, Patna 28 September-7th October 2004. Yojana November 2001, pp.42

Kumar and Mathur, 1996, "Agriculture in Future: Demand-Supply Perspective for the Ninth Five Year Plan", Economic and Political Weekly, Vol. 31, No. 39, pp. A 133-139.

Kalam and Rajan, 1998, A vision for the New Millennium.

Ruttan, Vernon W. 1956, "The contribution of technological progress to farm output 1950-1975", Review of Economics and Statistic, pp 61-69

R.K. Datta, Director, 1996, “Central Sericulture Research and Training Institute”, The Hindu Survey of Indian Agriculture, pp 127.

Singh P.K. 2002, "Next phase of economic reforms: Strategies for agriculture”, Arth- Vikash, January-June, pp 2126.

S. Ayyoppan, 1997, “Towards a blue revolution, Central Institute of Freshwater Aquaculture”, Kausalyaganga, Bhubaneshwar, Orissa, The Hindu Survey of Indian Agriculture , pp. 118-119.

Singh P.K., 2002, "Next Phase of Economic Reforms: Strategies for Agriculture”, Arth-Vikash, pp. 21-26, JanuaryJune.

The Hindu Survey of Indian Agriculture 2004, pp. 107

Trz, Xavier et al. 2001, "Agricultural Productivity Growth and Poverty Alleviation", Development Policy Review: 19:4. pp. 449-466, 2001.

Yojana November 2001, pp. 22and pp. 42.

1. Name:

\section{GENERAL QUESTIONNAIRES}

2. Father' Name:

3. Address:

4. Age:

5. Sex:

Male-

Female-

6. Main Occupation:

7. Supplementary Occupation:

8. Land size:

Small

Marginal

Big

9. Use of land:

Agriculture

Poultry

Fishery

Dairy

Others

10. Occupation wise:

1. Agriculture:

a. Crops Types:

b. Farming Methods: Organic Inorganic

11. If organic:
a. Total input
b. Total output
c. Profit

12. If Inorganic methods:
a. Total input
b. Total output
c. Profit

13. Others:
a. Total input
b. Total output
c. Profit 